Paweł Ukielski

\title{
EUROPA ŚRODKOWA W POLSKIEJ MYŚLI POLITYCZNEJ PO 1989 ROKU
}

Gdy w 1989 r. Polska odzyskiwała niepodległość po dekadach komunistycznego totalitaryzmu i sowieckiego zniewolenia, podobne przemiany miały miejsce w pozostałych krajach Europy Środkowej. Wspólnota losu Polski i jej sąsiadów w regionie - grupy średnich i małych państw - sięga zresztą znacznie głębiej: XIX-wiecznych wysiłków na rzecz uzyskania niepodległości od imperiów rozgrywających swoje interesy w regionie, krótkiego okresu niepodległości w latach 1918-1939, następnie II wojny światowej i czasów władzy komunistycznej. Geopolityczne położenie regionu, w Polsce określane jako między Rosja a Niemcami, do pewnego stopnia determinowało sytuację omawianych państw. Nic zatem dziwnego, że Europa Środkowa i Wschodnia stała się obiektem szczególnego zainteresowania Polski po 1989 r.

\section{Korzenie środkowoeuropejskiej myśli politycznej w Polsce}

Po 1989 r. polska myśl polityczna wobec regionu pełnymi garściami czerpie z wcześniejszych tradycji intelektualnych. Wspomnieć tu należy przede wszystkim o koncepcjach wypracowanych u zarania istnienia odnowionego państwa polskiego po 1918 r. - idei jagiellońskiej z wypływającym z niej programem federacyjnym dla Rzeczpospolitej oraz projekcie Międzymorza. Wbrew potocznym przekonaniom, jak słusznie dowodzi Paweł Kowal, nie są to koncepcje tożsame - wręcz przeciwnie, Międzymorze jako pomysł późniejszy wypływa z niemożności praktycznej realizacji projektu federacyjnego, co stało się oczywiste dla jego autora, Józefa Piłsudskiego po pokoju ryskim w marcu 1921 r. $^{1}$ Przed zakończeniem wojny polsko-bolszewickiej głównym programem

1 P. Kowal, A. Orzelska-Stączek (2019): Inicjatywa Trójmorza: geneza, cele i funkcjonowanie, Warszawa: Instytut Studiów Politycznych Polskiej Akademii Nauk, s. 21. 
politycznym była koncepcja federacji wywodzona z ugody hadziackiej (1658 r.) wraz z postulatem powolania federacji Polski, Litwy i Rusi - dziedziczacych po I Rzeczpospolitej ${ }^{2}$. Akceptacja istnienia Związku Sowieckiego i ułożenie z nim formalnych relacji w Rydze kładło kres tej koncepcji i otwierało drogę dla prometeizmu (działań mających charakter antyimperialny i antykomunistyczny, dążących do rozbijania/osłabiania powołanego formalnie do życia w $1922 \mathrm{r}$. ZSRS). Otwierało to również pole dla rozmaicie definiowanych koncepcji stworzenia Międzymorza - programu politycznego, który miał na celu organizację przestrzeni politycznej między Rosją a Niemcami (w różnych konfiguracjach idee te obejmowały obszar od Finlandii po Rumunię czy Jugosławię) $)^{3}$. Z biegiem czasu Polska coraz bardziej wycofywała się z planów realizacji idei prometeizmu ( $w$ myśl pragmatycznego niezadrażniania relacji ze Związkiem Sowieckim). Idea Międzymorza była znacznie bardziej żywotna - również $\mathrm{w}$ latach 30 . XX wieku podejmowano próby różnych form jej realizacji (jak np. Blok Agrarny) ${ }^{4}$.

W czasie II wojny światowej idea bliskiej współpracy państw Europy Środkowej stała się jednym z głównych wektorów polityki prowadzonej przez gabinet Władysława Sikorskiego. Szczególne miejsce zajmowały w niej koncepcje federacji polsko-czechosłowackiej, które w latach 1941-1942 przybrały bardzo konkretne kształty i przewidywały stosunkowo silną integrację obu państw i instytucjonalizację ich związku. Projekty federalizacyjne okazały się jednak niemożliwe do realizacji wobec sprzeciwu Stalina i od roku 1943 zostały de facto odłożone ad actas.

Kiedy na Starym Kontynencie zapadła żelazna kurtyna, dzieląc Europę na komunistyczny, podporządkowany Związkowi Sowieckiemu, Wschód i kapitalistyczny Zachód, nie tylko wszelkie pomysły regionalistyczne w Europie

2 Ibid., s. 19.

3 Por.: P. Okulewicz (2003): Koncepcja „Międzymorza” jako próba stworzenia strefy bezpieczeństwa między Niemcami a Rosja w okresie międzywojennym, w: O nowy ksztalt Europy. XX-wieczne koncepcje federalistyczne $w$ Europie Środkowo-Wschodniej i ich implikacje dla dyskusji o przyszłości Europy, red. J. Kłoczowski, S. Łukasiewicz, Lublin: Instytut Europy Środkowo-Wschodniej, s. 62-73.

4 P. Kowal, Orzelska-Stączek, op. cit., s. 24-26.

5 Por.: H. Bartoszewicz (1995): Zwiazek Sowiecki wobec koncepcji federacyjnych $w$ Europie Środkowo-Wschodniej, „Studia Polono-Danubiana et Balcanica” VII, „Zeszyty Naukowe Uniwersytetu Jagiellońskiego" nr MCLXXVII, Prace Historyczne, z. 118, s. 137-147; T. Kisielewski (2003): Projekt federacji polsko-czechosłowackiej i idea federacji środkowoeuropejskiej. Polityka polska i czechosłowacka w kontekście polityki mocarstw koalicji antyniemieckiej (1939-1943), w: O nowy ksztalt Europy..., s. 129-150. 
Środkowej stały się utopią (po którą praktycznie nikt nie sięgat), ale ze słownika politycznego, jako zbędne, zniknęło samo pojęcie Europy Środkowej, skoro w żaden sposób nie przystawało do rzeczywistości geopolitycznej. Bodaj ostatnim autorem wykazującym swoistość regionu był wybitny polski historyk, Oskar Halecki, który w swoim dziele Historia Europy - jej granice i podzialy w 1950 r. wyodrębniał dwie Europy Środkowe - zachodnią (niemiecką) oraz wschodnią (nieniemiecką, pokrywającą się mniej więcej z wcześniejszymi koncepcjami Tomaša Garrigue’a Masaryka) ${ }^{6}$. Późniejsza współpraca ograniczała się do tzw. bloku wschodniego i faktycznego narzucenia jej regul przez Związek Sowiecki w postaci Rady Wzajemnej Pomocy Gospodarczej (RWPG - powołanej do życia w 1949 r. w odpowiedzi na plan Marshalla) oraz Układu Warszawskiego (powstałego w 1955 r. w odpowiedzi na remilitaryzację RFN i jej przystąpienie do NATO).

W tym czasie Europa Środkowa i Wschodnia była przedmiotem zainteresowania polskiej myśli politycznej na emigracji - najważniejsze środowisko stanowiła tu paryska Kultura, która wszakże skupiała się głównie na wschodnich sąsiadach Polski. W kraju pierwszym ugrupowaniem, które podjęło tematykę państw regionu w kontekście przyszłej współpracy po wyrwaniu się spod sowieckiej dominacji, był podziemny Ruch, w którego deklaracji programowej Mijają lata... znaleźć można postulat przyjacielskiej kooperacji z narodami Europy Środkowo-Wschodniej (w ramach postępującej integracji), co miałoby stanowić przeciwwagę (trzecią siłę) dla dwóch ekspansywnych organizacji państwowych (Rosji i Niemiec) ${ }^{7}$. Projekt Ruchu był na tyle niesprecyzowany, że trudno jednoznacznie określić, czy bliżej mu do koncepcji federalistycznych czy idei Międzymorza.

Rozwój myśli politycznej skierowanej na państwa i narody regionu nastąpił wraz z pojawieniem się opozycyjnych ugrupowań i organizacji po $1976 \mathrm{r}$. Podobnie jak w przypadku środowiska paryskiej Kultury, również krajowi opozycjoniści główny nacisk kładli na relacje z narodami sąsiadującymi z Polską od wschodu, uznając, że kwestia jej dawnych wschodnich terytoriów oraz ułożenia sobie przyjaznych relacji z narodami I Rzeczpospolitej jest kluczowa dla przyszłej polskiej niepodległości. O południowych sąsiadach Polski (a szerzej - państwach podległych Związkowi Sowieckiemu) była z kolei częściej mowa w kontekście wspólnoty losu i możliwej wspólpracy na rzecz wyzwolenia (a następnie - przeciwdziałania ponownemu zniewoleniu).

${ }^{6}$ O. Halecki (2000): Historia Europy - jej granice i podziaty, Lublin, s. 121-136.

7 Deklaracja programowa „Mijają lata ...” Ruchu niepodległościowego, dostępna na: http://ruchniepodleglosciowy.pl/program-mijaja-lata/ [dostęp: 25.06.2019]. 
$\mathrm{W}$ okresie przedsolidarnościowym sprawy regionu pojawiały się $\mathrm{w}$ myśli, programach i publikacjach Polskiego Porozumienia Niepodległościowego, Komitetu Obrony Robotników, Ruchu Obrony Praw Człowieka i Obywatela czy Ruchu Młodej Polski. Teksty poświęcone tej tematyce ukazywały się w licznych pismach drugiego obiegu' ${ }^{8}$. Szczególne miejsce dla współpracy opozycji polskiej z podobnymi ośrodkami $\mathrm{w}$ regionie (zwłaszcza czechosłowackimi i węgierskimi), mimo oczywistej dysproporcji siły i potencjału, widzieli przedstawiciele Komitetu Samoobrony Społecznej KOR, którzy starali się utrzymywać z nimi jak najintensywniejsze kontakty (do najważniejszych wydarzeń w tym zakresie należy zaliczyć dwa spotkania w 1978 r. przedstawicieli KSS KOR z reprezentantami Karty 77 w Karkonoszach) 9.

W czasie tzw. karnawału Solidarności polskie środowiska opozycyjne skupione były na polityce wewnętrznej, kwestie międzynarodowe ( $w$ tym środkowoeuropejskie) pozostawały poza sferą zainteresowań nowopowstałego ruchu. Było to spowodowane dążeniem do swoistego skracania linii frontu - wystarczająco wiele wysiłku i działań kosztowało utrzymywanie Solidarności i jej zdobyczy w warunkach ciągłych napięć z komunistyczną władzą, by jeszcze angażować się w politykę międzynarodową. Jedynym (ale wyjątkowo głośnym i szeroko komentowanym) odstępstwem od tej taktyki było słynne Postanie do ludzi pracy Europy Wschodniej - odezwa uchwalona przez I Krajowy Zjazd Delegatów Niezależnego Samorządnego Związku Zawodowego Solidarność. Dokument ten, podkreślający wspólnotę losu narodów Albanii, Bułgarii, Czechosłowacji, Niemieckiej Republiki Demokratycznej, Rumunii, Węgier i wszystkich narodów Związku Sowieckiego, wyrażał przekonanie, że wkrótce również w tych państwach powstaną wolne związki zawodowe, które będą mogły podjąć współpracę z Solidarnością ${ }^{10}$. Posłanie wywołało nie tylko bardzo nieprzychylne reakcje komunistycznych władz Polski i pozostałych krajów obozu (w tym przywódcy ZSRS Leonida Breżniewa, który uznał je za dokument niebezpieczny i prowokacyjny), ale również wielu przywódców Solidarności uważało je za błąd i niepotrzebne drażnienie komunistów. Jednocześnie zyskało ono masowe poparcie szerokich kręgów opozycyjnych.

${ }^{8}$ Więcej: J. Skórzyński (2014): Polska opozycja wobec Europy Środkowo-Wschodniej - koncepcje i struktury, w: tenże, Na przekór geopolityce. Europa Środkowo-Wschodnia w myśli politycznej polskiej opozycji demokratycznej 1976-1989, Warszawa: Kancelaria Prezydenta Rzeczypospolitej Polskiej, s. 18-33.

9 Ł. Kamiński, P. Blažek, G. Majewski (2009): Ponad granicami. Historia Solidarności Polsko-Czechosłowackiej, Wrocław, s. 126-130.

10 G. Majchrzak, J. M. Owsiński (oprac.) (2011): I Krajowy Zjazd Delegatów NSZZ „Solidarność”. Stenogramy, t. 1 - I tura, Warszawa: Instytut Pamięci Narodowej, s. 1044-1045. 
Wraz z wprowadzeniem stanu wojennego i złamaniem kruchego status quo między władzami a opozycją, refleksja nad miejscem Polski w regionie i stosunkami z innymi narodami Europy Środkowej i Wschodniej stała się znacznie bardziej widoczna w myśli politycznej. Powstały nowe pisma ( $A B C$, Nowa Koalicja, Niepodległość, Karta). Debatę nad tą tematyką kontynuowały też wcześniej istniejące periodyki (Obóz, czy Spotkania) ${ }^{11}$. Większość tekstów dotyczyła wprawdzie wschodnich sąsiadów Polski (ze szczególnym uwzględnieniem Ukrainy), niemniej również narody leżące na południe od Rzeczpospolitej znajdowały swoje miejsce w powstającej wówczas publicystyce.

Publicystyka polityczna uzupełniana była przez programy powstających (lub pozostających w podziemiu) ugrupowań politycznych, które odwoływały się do wspólnoty losów narodów, znajdujących się pod władzą komunistów. Działania te obejmowały zarówno programy polityczne i odezwy przygotowywane we własnym zakresie (lub wspólpracy różnych grup w Polsce) ${ }^{12}$, jak również próby współdziałania z kręgami opozycyjnymi z innych krajów regionu. Największą skalę uzyskały kontakty między opozycją polską i czechosłowacką, które przybrały formę quasi-instytucjonalną w postaci Solidarności Polsko-Czechosłowackiej, nawiązującej do tradycji spotkań granicznych w późnych latach 1970. Na początku 1989 r. powołana do życia została również Solidarność Polsko-Węgierska. Jak zauważa Jan Skórzyński, owocem działalności Solidarności Polsko-Czechosłowackiej nie byly nowe koncepcje polityczne, ale przenikanie - mimo szczelnie strzeżonych granic - ludzi, idei i pomystów, osmoza form i sposobów działania ${ }^{13}$. Podobnie można określić wpływ wszystkich pozostałych inicjatyw międzynarodowych, jednak to właśnie to przenikanie stanowiło dobry fundament pod koncepcje polityczne $\mathrm{w}$ regionie po $1989 \mathrm{r}$.

\section{Po 1989 r. - Grupa Wyszehradzka i CEFTA w drodze do Unii Europejskiej}

W 1989 r. w wyniku Jesieni Narodów państwa Europy Środkowej odrzuciły komunizm i wyzwoliły się spod sowieckiej dominacji. Proces zapoczątkowany w Polsce wraz z rozmowami przy Okrągłym Stole (6 lutego - 15 kwietnia

${ }^{11}$ Więcej: J. Skórzyński (2014): op. cit., s. 41-54.

${ }_{12}$ M.in. Posłanie do ujarzmionych narodów Europy Środkowej” przygotowane przez Tajną Komisję Zakładową NSZZ „Solidarność” Stoczni Gdańskiej im. Lenina podpisane przez kilkadziesiąt Komisji z wielu miast.

${ }_{13}$ Jan Skórzyński, op. cit., s. 60. 
1989 r. $)^{14}$, częściowo wolnymi wyborami $(4 \text { czerwca })^{15}$ i powołaniem niekomunistycznego premiera, Tadeusza Mazowieckiego (24 sierpnia) był kontynuowany w pozostałych krajach regionu. Kolejno Węgry, NRD, Czechosłowacja, Rumunia i Bułgaria odrzucały totalitarny reżim, dopełniając wyzwolenia regionu ${ }^{16}$. W tym samym czasie Kreml ustami Michaiła Gorbaczowa ogłosił zniesienie obowiązywania doktryny Breżniewa i państwa Europy Środkowej stanęły w obliczu możliwości prowadzenia niezależnej polityki zagranicznej oraz nieskrępowanej debaty publicznej na jej temat. Relacje w regionie stanowily jeden $\mathrm{z}$ istotnych wektorów tej dyskusji, choć (co zrozumiałe) nie najważniejszy, wobec palących kwestii związanych z upadającym Związkiem Sowieckim i zbliżeniem z Zachodem.

Już w sierpniu 1989 r. polski sejm wybrany w wyniku wyborów kontraktowych przyjął uchwałę potępiającą interwencję bratnia pomoc, uznając, że naruszyła ona prawo narodów do decydowania o własnym losie ${ }^{17}$. Uchwałę prezentował Adam Michnik, jeden z uczestników polsko-czechosłowackich spotkań opozycyjnych. Podobną uchwałę przyjął parlament węgierski. Rząd Czechosłowacji (znajdującej się w schyłkowej fazie normalizacji, wciąż przed przemianami politycznymi) zareagowal dość nerwowo i kuriozalnie - oświadczyl, że stanowiska obu parlamentów ingerują w wewnętrzne sprawy ich kraju ${ }^{18}$.

Najważniejszą koncepcją, niemal wprost wypływającą z doświadczenia wspólnoty losu opozycjonistów w państwach regionu, była współpraca wyszehradzka. Idea ta pojawiła się niemal natychmiast po odzyskaniu przez zainteresowane kraje wolności i suwerenności w zakresie polityki zagranicznej. Już w styczniu 1990 r. Pragę odwiedzili Adam Michnik oraz premier Tadeusz Mazowiecki, zaś wkrótce po ich wizytach nowo wybrany prezydent Czechosłowacji, Václav Havel złożył państwową wizytę w Warszawie, podczas której przemawiał do połączonych izb polskiego parlamentu. W swoim przemówieniu nawiązał do ideowej wspólnoty środkowoeuropejskich dysydentów i ich

14 Więcej: P. Codogni (2009): Okragły Stót, czyli polski Rubikon, Warszawa.

15 Wyczerpująco: P. Codogni (2012): Wybory czerwcowe 1989 roku. U progu przemiany ustrojowej, Warszawa.

16 Więcej na ten temat: A. Burakowski, A. Gubrynowicz, P. Ukielski (2009): 1989 - Jesień Narodów, Warszawa.

17 Oświadczenie Sejmu PRL w dwudziestą pierwszą rocznicę interwencji wojsk Układu Warszawskiego w Czechosłowackiej Republice Socjalistycznej, uchwalone 17 sierpnia 1989, w: Sprawozdanie stenograficzne z 5 posiedzenia Sejmu Polskiej Rzeczpospolitej Ludowej w dniach 16 i 17 sierpnia 1989 r., Warszawa: Biblioteka Sejmowa, s. $135-136$.

18 J. Tomaszewski (2007): Czechy i Stowacja, Warszawa, s. 279. 
wizji tej części kontynentu, po czym złożył ofertę nawiązania bliższej współpracy między Czechosłowacją, Polską i Węgrami ${ }^{19}$.

W tym samym czasie dość głośnym echem odbiła się zgłoszona przez Zbigniewa Brzezińskiego inicjatywa utworzenia jakiegoś rodzaju unii lub konfederacji polsko-czechosłowackiej. Koncepcja nienowa, sięgająca czasów II wojny światowej wzbudziła zaniepokojenie Pragi, która ustami swoich głównych przedstawicieli natychmiast zdystansowała się od podobnych hase ${ }^{20}$. Znacznie bardziej pozytywne reakcje myśl Brzezińskiego wzbudziła w Polsce. Oczywistym celem koncepcji Havla zgłoszonej w polskim Sejmie było zatem jasne wyznaczenie granic potencjalnej wspólpracy w regionie - ugrupowanie regionalne o niesprecyzowanej formie - tak, jakakolwiek forma związku państwowego - nie.

Pierwsze spotkanie w formule trójkąta (wówczas jeszcze nie wyszehradzkiego) odbyło się w Bratysławie 9 kwietnia 1990 r., jednak zakończyło się fiaskiem - nie było dobrze przygotowane pod względem dyplomatycznym, delegacje miały różny status i legitymację, a także odmienne cele. Po tym nieudanym spotkaniu Węgry i Czechosłowacja przejawiały mniejsze zainteresowanie kontynuacją, którą najbardziej zainteresowana była Polska. Niechęć Budapesztu i Pragi wynikała z rosnącego przekonania, że są na drodze integracji ze strukturami euroatlantyckimi bardziej zaawansowane i Warszawa mogłaby stanowić hamulec w drodze na Zachód. Ponadto więcej uwagi poświęcały współpracy w ramach Quadragonale (po przystąpieniu Czechosłowacji w maju $1990 \mathrm{r}$. - Pentagonale), w której to organizacji zarówno Węgrzy, jak i Czesi i Słowacy, nie widzieli miejsca dla Polski. Jasno to wyraził prezydent Havel w Bratysławie:

W związku z powstaniem strefy współpracy dunajsko-adriatyckiej Polacy wiedzą, że nie należą do tej przestrzeni historycznej, ale wyrażają uzasadnione obawy, że mogliby pozostać z boku integrujących się wspólnot w Europie i stać w tradycyjnie nieszczęśliwej strefie pomiędzy nowo powstającymi wielkimi Niemcami i jeszcze większym, przechodzącym dramatyczne przekształcenia Związkiem Sowieckim. Dlatego powstaje koncepcja swego rodzaju wariantu północnego, czyli

19 Przemówienie Prezydenta Czechosłowacji Václava Havla w Sejmie, 25 stycznia 1990 r., http://orka2.sejm.gov.pl/StenogramyX.nsf/0/367056EDB68DAEB2C1257 D20002CC70A/\$file/019_000006951.pdf(s. 79-89).

20 Wypowiedzi w tej sprawie polskiej prasie udzielili zarówno premier Marián Čalfa, jak i minister spraw zagranicznych Jiří Dienstbier. Por.: M. Szczepaniak (red.) (1996): Państwa wyszehradzkie. Systemy polityczne, gospodarka, wspótpraca, Poznań, s. 87. Również prezydent Havel starał się tłumić polski entuzjazm w tej kwestii. Por.: L. Lukášek (2010): Visegrádská skupina a její vývoj v letech 1991-2004, Praha, s. 17. 
raczej bałtyckiego, w którego skład wchodziłaby Polska, zaś Czechosłowacja jako logiczne ogniwo lączyłaby te dwie struktury, pełniąc rolę zwornika ${ }^{21}$.

Najprzychylniej do koncepcji współpracy trójstronnej po spotkaniu bratysławskim bez wątpienia odnosiła się strona polska, dla której perspektywa ewentualnego członkostwa w Pentagonale była wówczas dość mglista (choć nie zgadzano się z przedstawioną przez Havla wizją naszego regionu), a konieczność kooperacji w regionie - oczywista. Dlatego też, mimo świadomości niepowodzenia kwietniowego szczytu, wkrótce po nim minister Krzysztof Skubiszewski, przedstawiając w Sejmie priorytety polskiej polityki zagranicznej, nawiązał do koncepcji Havla. Potrzebę utworzenia ugrupowania polsko-czechosłowacko-węgierskiego wymienił na trzecim miejscu wśród priorytetów, mówiąc: Interesuje nas powiąanie nowe, przyszłe - w szczególności integracja $w$ trójkącie Czechostowacja-Polska-Wegry. W dalszej części swojego expose rozwinął kwestię współpracy regionalnej, zaś jako pierwszy został wymieniony Trójkąt Budapeszt-Praga-Warszawa: Interesuje nas wspótpraca $w$ trójkącie Czeska i Stowacka Republika Federacyjna Polska-Wegry. Spotkanie 9 marca 1990 r. [w rzeczywistości - 9 kwietnia - przyp. P.U.] $w$ Bratysławie byto pierwszym kontaktem $w$ tym zespole i przegladem niektórych wspólnych problemów. Konieczne jest wszakże, aby doprowadzić do systematycznej i dobrze przygotowanej pracy nad założeniami, treścia i forma wspótdziałania trzech państw, które tak wiele maja wspólnego ${ }^{22}$.

W tej sytuacji trudno dziwić się, że następne kroki w kierunku utworzenia ugrupowania regionalnego podjęła strona polska. Jak twierdzi Grzegorz Kostrzewa-Zorbas: dylemat, przed jakim stanęta polska dyplomacja to, czy pozwolić inicjatywie Havla zwiędnać, [... ] czy inicjatywę przejąć, wtaściwie uczynić wtasna i fundamentalnie zmienić tak, aby się stała bardziej akceptowalna dla polskiej opinii publicznej, dla polskich władz, a przede wszystkim dla Węgrów. Rozumowanie byto takie: jak przekonać Węgrów, proponując, aby to oni stali się gospodarzami. Temu nie mogliby nie ulec. I rzeczywiście. Zatem wymyśliliśmy Wyszehrad ${ }^{23}$.

Wysiłki polskiej dyplomacji zostały wsparte przez czynniki zewnętrzne. Wkrótce Praga jak i Budapeszt przekonały się, że rachuby na szybkie uzyskanie

${ }^{21}$ Cyt. za: M. Szczepaniak (red.) (1996): Państwa wyszehradzkie. Systemy polityczne, gospodarka, wspótpraca, Poznań, s. 88-89.

22 Expose ministra spraw zagranicznych Krzysztofa Skubiszewskiego w Sejmie - 26 kwietnia 1990 r., http://stosunki-miedzynarodowe.pl/teksty-zrodlowe/przemo wienia/1133-expose-ministra-spraw-zagranicznych-krzysztofa-skubiszewskiego-wsejmie-26-kwietnia-1990-r (dostęp: 04.09.2019).

23 Wypowiedź Grzegorza Kostrzewy-Zorbasa w filmie Europa Środkowa idzie na wolność. 
członkostwa w NATO i UE są jednak błędne. Co więcej, do tego doszły niepokojące sygnały zza oceanu - w czerwcu $1990 \mathrm{r}$. Henry Kissinger wystąpił z koncepcją utworzenia pasa państw neutralnych (Polska, Czechosłowacja, Węgry) ${ }^{24}$, co mogło grozić nie tylko odsunięciem w czasie członkostwa w NATO, ale wręcz zamknięciem przed krajami regionu drzwi Paktu. Jednocześnie, wraz z rosnącymi napięciami w Jugosławii, nieco mniej korzystnie prezentowała się szansa współpracy w ramach Pentagonale.

$\mathrm{Na}$ to wszystko nakładała się rosnąca aktywność dyplomacji sowieckiej, usiłującej wykorzystać obawy Zachodu oraz niepewność krajów środkowoeuropejskich. Pojawily się propozycje Moskwy, by odrodzeniu uległa RWPG w jakiejś zreformowanej, zmienionej formie. Według słów ówczesnego szefa polskiego rządu, Jana Krzysztofa Bieleckiego, Polska pierwsza jasno odmówiła uczestnictwa w jakichkolwiek projektach tego typu, mówiąc, że integrację możemy robić najwyżej z Czechosłowacją i Wegrami $i^{25}$.

Te wszystkie czynniki skłoniły partnerów do powrotu do idei współpracy regionalnej. W listopadzie 1990 r. prezydent Havel spotkał się z premierami Polski i Węgier, Tadeuszem Mazowieckim i Józsefem Antallem podczas szczytu KBWE w Paryżu, gdzie trzej przywódcy uzgodnili, że trzy kraje podpiszą deklarację o woli współpracy podczas szczytu w Budapeszcie ${ }^{26}$. Negocjacje w sprawie zwołania kolejnego szczytu trzech państw sfinalizowano na spotkaniu ministrów spraw zagranicznych w Budapeszcie 21 stycznia $1991 \mathrm{r}^{27}$ Kolejne dni wypełnione były rozmowami na temat treści i pól przyszłej współpracy, zakończone na następnym spotkaniu szefów dyplomacji całej trójki dzień przed rozpoczęciem szczytu, 11 lutego $1991 \mathrm{r}$. Wówczas delegacje osiągnęły ostatecznie porozumienie dotyczące zakresu przyszłej współpracy ${ }^{28}$. W kolejnych dniach $\mathrm{w}$ Budapeszcie odbyło się spotkanie prezydentów, premierów i ministrów spraw zagranicznych trzech państw, którego efektem było podpisanie 15 lutego wspólnej deklaracji na historycznym zamku w Wyszehradzie ${ }^{29}$.

24 L. Lukášek, op. cit., s. 17.

${ }^{25}$ Wypowiedź Jana Krzysztofa Bieleckiego w filmie Europa Środkowa idzie na wolność.

26 L. Lukášek, op. cit., s. 21.

27 M. Szczepaniak (red.) (1996): op. cit., s. 90.

28 L. Lukášek, op. cit., s. 27.

29 Deklaracja o współpracy Czeskiej i Słowackiej Republiki Federacyjnej, Rzeczypospolitej Polskiej i Republiki Węgierskiej w dążeniu do integracji europejskiej, 15.02.1991, http://www.visegradgroup.eu/documents/visegrad-declarations/visegraddeclaration-110412 (dostęp: 4.09.2019). 
Współpraca podjęta przez trzy państwa po podpisaniu Deklaracji wyszehradzkiej przedstawiana była niejednokrotnie jako wyraz istnienia tożsamości środkowoeuropejskiej. Mimo zawarcia sformułowań wskazujących na wspólne korzenie historyczne, kulturowe i religijne całej trójki, które znalazły się w dokumencie założycielskim, trudno się zgodzić, że wspólnota ta była motorem zawiązania Trójkąta Wyszehradzkiego. Już sam tytuł Deklaracji wskazuje na rzeczywisty cel istnienia tego ugrupowania - pole współpracy zawężone zostało w nim do dążenia do integracji europejskiej. Oczywiście, ograniczenia tego nie można analizować w oderwaniu od ówczesnej sytuacji geopolitycznej - sygnatariusze Deklaracji obawiali się koncepcji utworzenia odrębnej organizacji integracyjnej w Europie Środkowej, której istnienie mogłoby zamknąć możliwość uczestniczenia w zachodnich procesach integracyjnych. Niezależnie jednak od - uzasadnionych - przyczyn samoograniczenia pól kooperacji, trudno nie zauważyć, że nie sposób mówić o wspólnocie tożsamości, a jedynie wspólnocie celów ${ }^{30}$.

Pierwszy okres współpracy, obejmujący niespełna dwa lata, przyniósłpewne sukcesy. Wkrótce po powołaniu do życia Trójkąta udało się zlikwidować dwie instytucjonalne pozostałości sowieckiej dominacji - Radę Wzajemnej Pomocy Gospodarczej (28 czerwca 1991 r.) i Układ Warszawski (1 lipca 1991 r). Jeszcze w 1991 r. sowieckie wojska opuściły Czechosłowację i Węgry oraz rozpoczęły wycofywanie się z Polski (zakończone w 1993 r). W tym samym czasie toczyła się także ożywiona współpraca nakierowana na zbliżenie - kolejne dwa szczyty, w Krakowie (5-6 października 1991 r.) i w Pradze (5-6 maja 1992 r.), zbudowały podstawy do utworzenia Środkowoeuropejskiej Strefy Wolnego Handlu (CEFTA), ostatecznie powołanej do życia 21 grudnia $1992 \mathrm{r}$.

Polska była zwolennikiem jak najbardziej ścisłej współpracy i instytucjonalizacji Trójkąta, mimo zagrożeń, jakie mogłoby to nieść (głównie wynikających z możliwości pozostawienia Europy Środkowej samej sobie i uznania Wyszehradu za twór równoległy do Wspólnot Europejskich). Z jednej strony mogło to wynikać ze świadomości słabszej od partnerów sytuacji gospodarczej oraz wolniejszych postępów w negocjacjach (zarówno w sprawie udziału w integracji europejskiej i NATO, jak i wymarszu wojsk sowieckich), z drugiej zaś - dążenia do uzyskania statusu lidera w regionie. Ambicje

30 Debatę dotyczącą mitu założycielskiego Grupy Wyszehradzkiej podsumował Mateusz Gniazdowski, z jednej strony stawiając głównego czeskiego antagonistę współpracy wyszehradzkiej Václava Klausa twierdzącego, że Wyszehrad był możliwy pod naciskiem Zachodu, z drugiej zaś - intelektualistów odwołujących się do współpracy dysydenckiej oraz międzywojennych i wojennych koncepcji federalistycznych. Por.: M. Gniazdowski (2005): Possibilities and Constrains of the Visegrád Countries Cooperation within the EU, Foreign Policy Review 1-2, Budapest, s. 78-79. 
Polski wypływały również z dłuższej tradycji politycznej - międzywojennych koncepcji prometeizmu czy Międzymorza, a także projektów federacji czy konfederacji polsko-czechosłowackiej z czasów II wojny światowej i tuż po niej. W tym ostatnim przypadku tradycyjnie dyplomacja polska dążyła do większego zacieśniania kooperacji, podczas gdy czechosłowacka - wręcz przeciwnie - oczekiwała związku o znacznie luźniejszym charakterze, raczej konfederacyjnym.

Tym tradycjom strona czechosłowacka pozostała wierna również po odzyskaniu wolności w 1989 r. Dlatego też, razem z Budapesztem, Praga zajmowała bardziej powściągliwe stanowisko wobec zacieśniania współpracy wyszehradzkiej. Czesi i Węgrzy byli przeciwni instytucjonalizacji Trójkąta, nie chcieli też zbyt daleko idących zobowiązań wobec ugrupowania (a przede wszystkim - wobec Polski). Rezerwa wynikała bez wątpienia również stąd, że oba te państwa, zwłaszcza w 1991 r. wciąż jeszcze większą wagę przywiązywały do Pentagonale (później-Heksagonale) ${ }^{31}$.

Przełom lat 1992-1993 przyniósł załamanie współpracy wyszehradzkiej. Wraz z utworzeniem CEFTA i przeniesieniem na jej forum spraw gospodarczych, podziałem Czechosłowacji na dwie niepodległe republiki oraz decyzją szczytu Wspólnoty Europejskiej, że kandydatury państw ubiegających się o członkostwo w strukturach europejskich będą rozpatrywane indywidualnie, wygasł początkowy impet. Czesi uważali, że ich kraj jest liderem transformacji w Europie Środkowej i zdecydowanie łatwiej od partnerów uzyska członkostwo w strukturach euroatlantyckich, zaś podział Czechosłowacji postrzegali w kategoriach pozbycia się balastu. Na Słowacji natomiast od 1994 roku pod rządami Mečiara reguły demokratyczne były nagminnie łamane i można mówić o zmierzaniu tego kraju w kierunku autorytaryzmu. Również polityka zagraniczna Bratysławy została poddana istotnemu zwrotowi. Rząd wprawdzie werbalnie popierał zachodni kurs Słowacji, jednak czynami niejednokrotnie przeczył deklaracjom. Oficjalnie uznając członkostwo w NATO i Unii Europejskiej za główny cel słowackiej dyplomacji, zaczął zacieśniać stosunki z Moskwą.

Spośród wszystkich państw wyszehradzkich Polska była tym, które najdłużej podkreślało przywiązanie i żywotne zainteresowanie utrzymaniem tej formy wspólpracy. Niemal we wszystkich wystąpieniach parlamentarnych w Sejmie polscy ministrowie spraw zagranicznych używali określenia Wyszehrad

31 Wkrótce po przystąpieniu Polski i powstaniu Heksagonale nastąpił gwałtowny rozrost terytorialny tego ugrupowania (połączony ze zmianą nazwy na Inicjatywa Środkowoeuropejska). Wskutek tego, że członkowie byli bardzo zróżnicowani, mieli odmienne interesy oraz brakowało środków finansowych, Inicjatywa została szybko zmarginalizowana i utraciła znaczenie jako ugrupowanie międzynarodowe. 
i podkreślali olbrzymie zainteresowanie istnieniem Grupy ${ }^{32}$. Polska - w przeciwieństwie do bardziej pragmatycznej postawy władz czeskich czy węgierskich - zawsze w większym stopniu wyrażała zainteresowanie wspólpracą środkowoeuropejską jako taką, uznając ją za cel sam w sobie. Polska dyplomacja była przywiązana do idei wyszehradzkiej i dostrzegała w niej samoistną wartość, wręcz gotowa była widzieć ją jako trwałą strukturę, podczas gdy zarówno Praga, jak i Budapeszt traktowały Wyszehrad w najlepszym razie jako narzędzie do osiągania niektórych celów (likwidacja pozostałości postkomunistycznych i zbliżenie ze strukturami euroatlantyckimi) i główny nacisk kładły na relacje bilateralne.

W tym samym czasie, gdy współpraca wyszehradzka uległa załamaniu, okres dynamicznego rozwoju przeżywała CEFTA, będąca zwieńczeniem pierwszych dwóch lat ożywionej działalności wyszehradzkiej. W przeciwieństwie do współpracy politycznej w ramach Grupy Wyszehradzkiej, kooperacja na polu gospodarczym nie budziła kontrowersji wśród państw członkowskich.

Od 1994 r. podjęte zostały działania w celu przyspieszenia liberalizacji handlu w stosunku do terminów pierwotnie zapisanych w umowie. 29 kwietnia 1994 r. w Budapeszcie podpisano Protokół Dodatkowy do umowy. Dokument ten zmieniał zakres wzajemnych koncesji i skracał harmonogram ich realizacji, rozszerzał również zakres koncesji na towary rolne ${ }^{33}$. Dalsze przyspieszenie nastąpiło w wyniku spotkania premierów państw CEFTA 25 listopada $1994 \mathrm{r}$. w Poznaniu, na którym przyjęto Deklarację Poznańską, przewidującą szybsze znoszenie istniejących ograniczeń w handlu towarami rolno-spożywczymi oraz kolejne skrócenie (o rok) likwidacji ograniczeń we wzajemnym handlu artykułami przemysłowymi.

W Poznaniu zapadła jeszcze jedna, fundamentalna decyzja: państwa członkowskie CEFTA uznały, że - w przeciwieństwie do Grupy Wyszehradzkiej - ugrupowanie to nie jest zamknięte i sformułowały warunki członkostwa. Przyjęto trzy kryteria, w myśl których przyszły członek musiał:

- być członkiem GATT/WTO,

- mieć podpisaną z UE umowę stowarzyszeniową lub o tworzeniu strefy wolnego handlu dla dóbr przemysłowych,

- zostać zaakceptowany przez pozostałych członków CEFTA ${ }^{34}$.

32 Szerzej patrz: P. Ukielski (2005): The breakdown of the Visegrad cooperation in years 1993-1998, w: Z. Poláčková, Slovensko-české vzt'ahy v kontexte strednej Európy, Bratislava, s. 259-261.

33 A. Sołtysińska, P. Czubik (1997): CEFTA. Środkowoeuropejska Strefa Wolnego Handlu, Kraków, s. 6.

34 K. Żukrowska (2000): Środkowoeuropejskie Porozumienie o Wolnym Handlu, w: Europejskie struktury wspótpracy. Informator, red. S. Parzymies, Warszawa, s. 209. 
Na podstawie powyższych warunków do CEFTA przyjęte zostały kolejne państwa: Słowenia (1 stycznia 1996 r.), Rumunia (1 lipca 1997 r.), Bułgaria (1 stycznia 1999 r.) oraz Chorwacja (1 marca 2003 r.) (35 $^{35}$

Dotychczasowe sukcesy, obok braku problemów z implementacją kolejnych koncesji w handlu towarami przemysłowymi, spowodowały, że państwa członkowskie CEFTA postanowiły pójść krok dalej i zająć się kwestią wymiany rolno-spożywczej. Prace nad rozszerzeniem koncesji rolnych trwały od początku 1995 r., zaś ich efektem były trzy deklaracje ministrów rolnictwa przyjęte między styczniem a listopadem tego roku ${ }^{36}$. Efektem tych ustaleń było spotkanie 11 września 1995 r. w Brnie, gdzie premierzy państw CEFTA przyjęli Deklarację Brneńską. Jej postanowienia wprowadzał w życie Protokół Dodatkowy nr 3 (przyjęty 21 grudnia 1995 r.), poszerzający i pogłębiający koncesje rolne ${ }^{37}$.

Zmiany wprowadzone przez Protokoły Dodatkowe nr 2 i 3 sprawily, że od 1 stycznia 1996 r. poziom ochrony celnej w handlu artykułami żywnościowymi na obszarze CEFTA został zmniejszony o około 50\%. Natomiast szybkie tempo liberalizacji handlu towarami przemysłowymi umożliwiło już 1 stycznia 1997 r. powstanie strefy wolnego handlu w tym obszarze (wyjątki objęły jedynie około 2-3\% ogólnej wartości handlu pomiędzy krajami CEFTA) ${ }^{38}$. W ten sposób znacznie przyspieszono realizację postanowień Umowy z 1992 r. Strefę wolnego handlu towarami przemysłowymi osiągnięto 4 lata wcześniej niż pierwotnie zakładano, zaś w kwestii artykułów rolno-spożywczych zastosowano liberalizację dużo bardziej radykalną niż ustalono w Umowie. Zmiany te bardzo pozytywnie wpłynęly na warunki handlu w regionie, który, jedynie początkowo ograniczany, zaczął się dynamicznie rozwijać.

Przyspieszenie wprowadzone z dniem 1 stycznia 1996 r. było jednak ostatnim tak doniosłym wydarzeniem w dziejach CEFTA. Daleko idąca liberalizacja handlu rolnego wywołała konflikty między poszczególnymi jej członkami. W ramach CEFTA powstał podział na dwie grupy - zwolenników głębszej liberalizacji handlu rolnego, do której należały Czechy, Słowacja i Węgry oraz

35 Wykaz ten obejmuje okres do momentu przystąpienia do UE pierwszych państw należących do CEFTA. Wraz z akcesją do Unii 1 maja 2004 r. Czechy, Polska, Słowacja, Słowenia i Węgry musiały opuścić CEFTA (podobnie jak 1 stycznia 2007 r. - Bułgaria i Rumunia, zaś 1 lipca 2013 - Chorwacja). W późniejszych latach do CEFTA przystąpiły z kolei: Macedonia (2006 r.) oraz Albania, Bośnia i Hercegowina, Czarnogóra, Kosowo, Mołdawia, Serbia (2007 r.).

36 A. Soltysińska, P. Czubik, op. cit., s. 7.

37 M. Szczepaniak (1998): CEFTA na rozdrożu. Impas $w$ procesie integracji gospodarczej Europy Środkowej, Sprawy Międzynarodowe, nr 2, s. 93.

38 Ibid. 
państw uznających istniejący stopień otwarcia rynków rolnych za wystarczający - tego zdania były Polska, Rumunia, Bułgaria i Słowenia. Spory na tym tle nie ograniczały się jedynie do kontrowersji słownych - wewnątrz CEFTA dochodziło do licznych konfliktów handlowych. Najpoważniejsze dotyczyły handlu między Polską a Węgrami, choć też większe lub mniejsze nieporozumienia zdarzały się niemal w każdej konfiguracji bilateralnej ${ }^{39}$.

Wobec przeciwstawnych interesów jej członków dalsze postępy liberalizacji handlu zostały wstrzymane, zaś rokowania na kolejnych szczytach nie przynosily efektów. Kraje zainteresowane większym otwarciem rynków rolnych skorzystały z tej możliwości na zasadzie ustaleń bilateralnych, jednak umowy multilateralnej w tej kwestii nie udało się zawrzeć. Mimo zaledwie dość krótkiego ożywienia, współpraca w ramach CEFTA przyniosła olbrzymie korzyści - kraje do niej należące osiągnęly szeroki zakres wolnego handlu, jednocześnie udowadniając państwom UE, że są w stanie sprawnie wprowadzać mechanizmy liberalizacyjne, a także ćwiczyć ich implementację przed akcesją do Unii.

Wraz z malejącą aktywnością w ramach CEFTA, nastąpił powrót do współpracy wyszehradzkiej. Reaktywacja działalności Grupy nastąpiła po zaproszeniu Czech, Polski i Węgier do członkostwa w NATO (lipiec 1997 r.) oraz zmianach rządów w Czechach i na Słowacji. Formalnie Wyszehrad został w pełnym kształcie odnowiony 14 maja 1999 r. w Bratysławie podczas szczytu premierów czwórki. Przyjęty został wówczas najważniejszy wspólny dokument od czasu Deklaracji rozpoczynającej działalność Grupy - Treść wspótpracy wyszehradzkiej. Nowy dokument zdefiniował obszary współpracy wyszehradzkiej, zdecydowanie rozszerzając jej zakres. Znacznie większy nacisk położony został na realną, obywatelską jej płaszczyznę, po raz pierwszy odchodząc od założenia, że współpraca ta ma na celu wyłącznie pomóc w uzyskaniu akcesji do struktur euroatlantyckich ${ }^{40}$.

Najważniejszym politycznym celem, jaki postawiła sobie Grupa Wyszehradzka po reaktywacji działalności, było wsparcie Słowacji w jej aspiracjach zarówno dotyczących Paktu, jak i Unii Europejskiej. Na spotkaniu w Gerlachovie, które odbyło się 3 grudnia 1999 r. prezydenci podpisali deklarację, w której stwierdzono, że Stowacja powinna znaleźć się w NATO po następnej fali rozszerzenia ${ }^{41}$. Wsparcie Słowacji ze strony pozostałej trójki państw wyszehradzkich

39 A. Orzelska (2002): Wspótpraca regionalna w Europie Środkowej i Wschodniej, Studia Polityczne, nr 13, s. 288.

40 Contents of Visegrád cooperation 1999, http://www.visegradgroup.eu/coope ration/contents-of-visegrad-110412

41 P. Ukielski (2001): Słowacja, w: Europa Środkowo-Wschodnia 1999, Warszawa, s. 183. 
nie ograniczało się do werbalnego wygłaszania poparcia dla członkostwa Bratysławy w Pakcie, ale obejmowało również bardzo konkretne i szczegółowe rady, niezwykle przydatne stronie słowackiej. Czechy, Polska i Węgry były świeżo upieczonymi członkami Sojuszu. Dzięki temu mogły zaoferować Słowacji informacje z pierwszej ręki dotyczące standardów NATO, oczekiwań i wymagań Sojuszu wobec państw kandydujących oraz własnych doświadczeń z procesem rozszerzenia. Wszystkie trzy kraje miały własny żywotny interes we włączeniu Słowacji do strefy stabilności, gdyż każdy z nich ma z tym państwem wspólne granice i istnienie szarej strefy bezpieczeństwa w sercu Europy Środkowej byłoby dla nich zjawiskiem bardzo negatywnym ${ }^{42}$. Wysiłki słowackie, przy poparciu partnerów wyszehradzkich, zakończyły się sukcesem - w 2002 r. Bratysława została zaproszona do członkostwa w Pakcie i została jego pełnoprawnym członkiem 29 marca 2004 r. Współpraca w tym okresie mogła rokować, że Grupa Wyszehradzka stanie się silniejszym sojuszem politycznym, czego zawsze chciała strona polska.

Polskie oczekiwania, że Grupa Wyszehradzka okaże się zwartym sojuszem politycznym, zostały jednak zweryfikowane w końcówce negocjacji akcesyjnych z Unią Europejską. Ugrupowanie nigdy nie było w stanie przemawiać jednym głosem $\mathrm{w}$ sprawach unijnych (jedynym wyjątkiem pozostała kwestia dalszego rozszerzania UE - w tej sprawie kraje wyszehradzkie zawsze opowiadały się za prowadzeniem polityki otwartych drzwi), ale również w kwestii konkretnych rozwiązań akcesyjnych. Z pełną mocą różnice te wyszły przy okazji negocjacji dopłat bezpośrednich dla rolnictwa, otwarcia rynków pracy starych członków UE dla pracowników z państw przystępujących czy kwestii zmiany systemu głosowania w Radzie UE. W tych negocjacjach Polska zajmowała zazwyczaj najtwardsze stanowisko i oczekiwała wsparcia pozostałych państw wyszehradzkich. Polska dyplomacja uważała przy tym, że wspólne stanowisko całej czwórki będzie korzystne dla wszystkich i pomoże wynegocjować lepsze warunki akcesji. Czechy, Słowacja i Węgry, które wprawdzie również nie zgadzały się z rozwiązaniami forsowanymi przez unijnych negocjatorów, często po początkowym wsparciu Polski dochodziły do wniosku, że twarde stanowisko, zwłaszcza w sprawach prestiżowych, ale jednak mniej istotnych, może przynieść im więcej szkód niż korzyści.

${ }^{42}$ M. Nicolini (2001): An Ally „De Facto”: Slovakia on Its Road to NATO Membership, Slovak Foreign Policy Affairs, vol. II, no. II, Fall, s. 17. 


\section{Po wejściu do UE - nowe wyzwania w regionie}

W 2004 r. cel zadeklarowany w chwili powoływania ugrupowania do życia - członkostwo w NATO i Unii Europejskiej całej czwórki - został spełniony. W tej sytuacji pojawily się pytania o przyszłość Grupy: czy po wejściu Czech, Polski, Słowacji i Węgier do UE i NATO nadal będzie ona istnieć, a jeśli tak, to $\mathrm{w}$ jakiej formie? W tym samym czasie z przyczyn formalnych wszak wszyscy nowi członkowie UE musieli opuścić CEFTA.

Jak się szybko okazało, przywódcy wszystkich krajów uznali, że istnienie Grupy Wyszehradzkiej przynosi korzyści i nikt nie postawił na poważnie pytania o sens jej istnienia. 12 maja 2004 r. w czeskiej Kroměřízi odbył się szczyt premierów, podczas którego przyjęto nową deklarację definiującą współpracę po wejściu do UE. Nowy dokument stwierdzał osiągnięcie celów zawartych w Deklaracji z 1991 r. oraz podkreślał wolę państw członkowskich, aby współpracę kontynuować. Jako główne pola kooperacji określono wzmacnianie tożsamości środkowoeuropejskiej poprzez działania i inicjatywy regionalne, wspólny wkład w rozwój Unii Europejskiej, zwłaszcza poprzez wspieranie aspiracji państw kandydujących do członkostwa oraz kształtowanie polityki unijnej wobec państw Europy Wschodniej i Południowowschodniej ${ }^{43}$.

Nowa Deklaracja zakończyła burzliwy etap w dziejach Grupy Wyszehradzkiej. Od tego czasu nie było spektakularnych załamań współpracy, ale nie było także efektownych wzlotów. Polska pogodziła się, że Grupa nie stanie się trwałym sojuszem politycznym, a jedynie będzie się (w przypadku zbieżnych interesów poszczególnych partnerów) takim stawać w niektórych momentach.

Przystąpienie wszystkich członków Grupy do instytucji euroatlantyckich nie zakończyło jednak debaty na temat roli Polski w regionie - wręcz przeciwnie - wraz z zakończeniem etapu ucieczki ze Wschodu w Polsce pojawil się ostry i realny spór o politykę zagraniczną, zarówno w kwestiach strategii, jak i taktyki. Marek Cichocki określił ten podział jako spór suwerenistów z globalistami i wydaje się, że dobrze opisuje on kolejnych kilkanaście lat polskiej debaty o polityce zagranicznej, w tym miejsca, jakie zajmuje w niej Europa Środkowa ${ }^{44}$. W tym kontekście należy postrzegać toczącą się od lat debatę zwolenników polityki jagiellońskiej i piastowskiej,

43 Declaration of Prime Ministers of the Czech Republic, the Republic of Hungary, the Republic of Poland and the Slovak Republic on cooperation of the Visegrád Group countries after their accession to the European Union, http://www.vi segradgroup.org/documents/visegraddeclaration2004.pdf

${ }^{44}$ M. Cichocki (2010): Szkice z polskiej podmiotowości, w: (red.), Rzeczpospolita na arenie międzynarodowej. Idee i praktyczne dylematy polityki zagranicznej, w: J. Kloczkowski, T. Żukowski, Warszawa-Kraków, s. 70. 
czyli - w największym uproszczeniu sprawę ujmując - zwolenników aktywnego budowania pozycji Polski w regionie (z różnymi punktami ciężkości, na wschodzie lub na południu) oraz zwolenników tezy o braku potencjału, by stać się lokalnym liderem i samodzielne układać relacje z głównymi graczami w Europie i na świecie.

W polskiej polityce zagranicznej po 2004 r. można wyodrębnić trzy okresy: 2004-2007/2008 (z częściowym przedłużeniem do 2010, kiedy do czasu tragicznej śmierci pod Smoleńskiem prezydent Lech Kaczyński starał się kontynuować wcześniejszą linię polityczną) - rekonstrukcja; 2007/2008-2014/2015 - mała stabilizacja; od 2015 - próba suwerenizmu ${ }^{45}$. Przenosząc ten podział na politykę w regionie, można uznać, że pierwszy i trzeci są (w uproszczeniu) okresami jagiellońskimi (przy czym pierwszy raczej o wektorze wschodnim, a trzeci - południowym), zaś drugi - piastowskim.

Jagiellońska polityka Lecha Kaczyńskiego (któremu premierzy Kazimierz Marcinkiewicz i Jarosław Kaczyński pozostawili rolę lidera w polityce zagranicznej) nakierowana była na rekonstrukcję polskich więzi politycznych w Europie Wschodniej i (w znacznie mniejszym stopniu) Środkowej. W tym sensie, zgodnie z podziałem Pawła Kowala, była to koncepcja bliższa projektom federacyjnym z okresu międzywojennego niż Międzymorzu. Konkretem, na którym miała się ta odbudowa opierać, stała się energetyka - współpraca $\mathrm{w}$ tym zakresie miała uniezależnić kraje regionu od rosyjskiej dominacji ( $\mathrm{w}$ przypadku dostawców - umożliwić dostawy z pominięciem rosyjskiego pośrednictwa, w przypadku odbiorców - poprzez dywersyfikację dostaw) ${ }^{46}$. Polityka prezydenta Kaczyńskiego miała w kraju licznych krytyków zarzucających mu antyrosyjskość i sprzeciwiających się polityce jagiellońskiej.

Wraz z przejęciem władzy przez rząd Donalda Tuska, w którym tekę ministra spraw zagranicznych otrzymał Radosław Sikorski, nastąpił istotny zwrot w polskiej polityce zagranicznej. Sikorski zadeklarował wolę poprawy relacji z Berlinem i Moskwą i konsekwentnie dążył do tego celu, znacząco osłabiając aktywność w Europie Środkowej (a także Wschodniej). Założenia tej zmiany zdefiniował post factum $\mathrm{w}$ głośnym artykule Lekcje historii, modernizacja $i$ integracja. W tej swoistej deklaracji programowej stwierdzil, że Polska powinna zrezygnować z jagiellońskich ambicji mocarstwowych i odstąpić od dążenia do osiągnięcia statusu jagiellońskiego mocarstwa regionalnego", zaś rząd powinien prowadzić politykę piastowsk $\mathfrak{q}^{47}$.

${ }^{45}$ Zob.: P. Kowal, P. Ukielski (2014): Ćwierć wieku polskiej polityki zagranicznej (1989-2014), Horyzonty polityki, vol. 5, no. 11, s. 43-48. Tekst powstał w 2014 r., więc ostatni okres jeszcze się w nim nie pojawil.

${ }^{46}$ P. Kowal, A. Orzelska-Stączek, op. cit., s. 35.

${ }^{47}$ R. Sikorski (2009): Lekcje historii, modernizacja i integracja, Gazeta Wyborcza, 29 VIII. 
Tekst ministra Sikorskiego wywołał szeroką debatę poświęconą strategicznym założeniom polityki zagranicznej Rzeczpospolitej. Tezy postawione przez szefa dyplomacji wsparł Rafał Ziemkiewicz, który poszedł znacznie dalej, twierdząc, że zachowanie suwerenności wyszło poza realne możliwości Polski, w związku z czym należy wejść do niemieckiej strefy wpływów, gdyż alternatywą jest jedynie pozostanie rosyjskim satelitą ${ }^{48}$. Jednocześnie jednak sam zauważał, że szansa na bycie liderem w Europie Środkowej istniała, jednak była marnowana. Na tę niekonsekwencję argumentacji Sikorskiego zwracał uwagę Łukasz Warzecha, który stwierdzil, że minister gładko przeszedł od krytyki środków do krytyki strategii, nie zwracając uwagi na fundamentalną różnicę między oboma polami debaty ${ }^{49}$. Krytykę całkowitego skupienia się na Rosji i Niemczech kosztem partnerów z Europy Środkowej i Wschodniej przeprowadził również Paweł Kowal, który skonkludował: Prawdziwy realizm to aktywna polityka Polski $w$ regionie wbrew oczekiwaniu, byśmy siedzieli cicho, to ścisłe więzy z Ukrainą, Litwą, państwami wyszehradzkimi ${ }^{50}$. Mały realizm Sikorskiego Marek Cichocki $\mathrm{z}$ kolei określił mianem putapki minimalizmu ${ }^{51}$.

Mimo toczącej się debaty, zasadnicze, piastowskie założenia polityki Sikorskiego nie uległy zmianie, nawet jeśli odnotujemy pewne ocieplenie stosunku do Grupy Wyszehradzkiej, jakie można zauważyć w 2012 r. wraz z przygotowaniami, a następnie objęciem prezydencji w tym ugrupowaniu. Również inauguracja Partnerstwa Wschodniego w 2009 r. nie zmienia tej opinii, gdyż nie stanowi ono próby budowania przez Polskę pozycji w regionie, lecz jest elementem Europejskiej Polityki Sąsiedztwa.

\section{Trójmorze - nie Międzymorze czy nowe Międzymorze?}

Krytyka polityki Sikorskiego i przekonanie, że Polska powinna być bardziej aktywna w regionie i przynajmniej próbować wykorzystywać swój potencjał oraz szanse, zaowocowała debatą koncepcyjną nad możliwością powrotu do idei międzymorskiej. Postulat taki sformułował Marcin Kędzierski, który proponował realizację jednego z czterech możliwych wariantów neojagiellonizmu. Jego zdaniem, najodpowiedniejsza jest koncepcja $A B C$ polegająca na ścistej wspótpracy pomiędzy państwami battyckimi, Grupa Wyszehradzka, Rumunia i w mniejszym stopniu Bułgaria, a także krajami Batkanów Zachodnich (Chorwacja, Serbia,

\footnotetext{
48 R. Ziemkiewicz (2009): Polityka realna - czyli jaka?, Rzeczpospolita, 26 IX.

49 Ł. Warzecha (2009): Realizm nie na kolanach, Rzeczpospolita, 10-11 X.

50 P. Kowal (2009): Nie żegnajmy się z Giedroyciem, Rzeczpospolita, 3-4 X.

51 M. Cichocki (2009): W putapce minimalizmu, Tygodnik Powszechny, 6 X.
} 
Stowenia). W krótkim okresie powinna być ona negatywna (wspótpraca), a w dalszej perspektywie pozytywna (quasi-federacyjna). Podstawą nowej polityki miało być 10 punktów, nazwanych dziesięcioma działaniami neojagiellońskimi, których realizacja miałaby pozwolić Polsce sprawdzić, na ile realistyczne są jej ambicje w regionie. Jak podsumował autor: Jeśli nie chcemy się poddać na starcie i nie chcemy przyją́ pozycji petenta, musimy uwierzyć, że wizja Unii Środkowoeuropejskiej jest osiagalna ${ }^{52}$.

Tekst Kędzierskiego wzbudził szerokie zainteresowanie i liczne polemiki. Część autorów krytykowała go za nadmierny idealizm, czy wręcz utopijność - Tomasz Krawczyk postulował, by powstrzymać się z podobnymi projektami do momentu, gdy Polska stanie się wystarczająco silna, dobrze rozwinięta i funkcjonująca tak, by być atrakcyjnym liderem dla pozostałych państw regionu ${ }^{53}$. Pomysł polskiego przywództwa w regionie krytyce poddali też Tomasz Szatkowski i Tomasz Gabiśs, uznający, że obecnie Polska nie jest wystarczająco atrakcyjna i silna, by taką pozycję sobie wywalczyć. Szatkowski wprost stwierdza: To Niemcy, a nie Polska, sa dziś $w$ stanie sprawować hegemonię w regionie Europy Środkowej. Gdyby Polska była rzadna, mogłaby z nimi rywalizować. Ale nie jest $t^{54}$. Z kolei Gabiś analizuje różne sfery, w których Polska mogłaby stać się atrakcyjna dla sąsiadów i w ten sposób zostać liderem i dochodzi do wniosku: Jeśli - jak się wydaje - nie jesteśmy liderem gospodarczym, kulturalnym, naukowym, sportowym Europy Środkowo-Wschodniej, jeśli nie wzbudzamy jako naród i kraj jakiegoś ponadprzeciętnego zainteresowania u narodów tego regionu, jeśli nie dysponujemy realnymi zasobami finansowymi, instytucjonalnymi itd., których można by użyć przy skupianiu wokót siebie mniejszych krajów, jeśli nie jesteśmy „najbardziej kochanym” narodem Europy Środkowo-Wschodniej, jesli znaczaco nie przewyższamy innych narodów regionu, to na czym wtaściwie mielibyśmy opierać swoje roszczenia do regionalnego przywództwa politycznego? ${ }^{55}$. Z kolei Michał Kuź z podobnych przesłanek wnioskuje, że taka polityka w regionie jest możliwa, jednak nie należy o tym głośno mówić, ale po cichu i sprytnie działać: Podczas gdy my wciąż mówimy o projekcie neojagiellońskim, którego nie ma, Berlin twardo milczy o niemieckiej Europie, która na

${ }^{52}$ M. Kędzierski, Czas na Międzymorze, https://nowakonfederacja.pl/czas-namiedzymorze/ (dostęp: 24.08.2019).

53 T. Krawczyk, Ucieczka w utopię, https://klubjagiellonski.pl/2015/01/20/ krawczyk-ucieczka-w-utopie/ (dostęp: 24.08.2019).

54 T. Szatkowski, Nie ma przywództwa bez sity, http://nowakonfederacja.pl/niema-przywodztwa-bez-sily/ (dostęp: 24.08.2019).

55 T. Gabiś, Polska w Europie (Środkowo-Wschodniej), https://nowakonfedera cja.pl/gabis-polska-w-europie-srodkowo-wschodniej/? $t \mathrm{t}=1566475606 \&$ \&uccess message $=19676 \_1 \& \_$target $=3014 \#$ cred_form_19676_1 (dostęp: 24.08.2019). 
naszych oczach powstaje. I postuluje: Musimy jednak być zdecydowani, sprytni i cierpliwi jednocześnie. A co najważniejsze, tak jak Niemcy przestały otwarcie wspominać o rozmaitych „Mitteleuropach”, tak i my musimy przestać mówić o Jagiellonach. To niczemu już w polityce nie stuży ${ }^{56}$.

Odmiennie natomiast możliwość polskiego liderowania w regionie postrzegali Jacek Bartosiak i Radosław Zenderowski. Bartosiak stwierdził wprost: Przeznaczeniem Polski jest przewodzić Europie Środkowo-Wschodniej. Być zwornikiem wymiany gospodarczej pótnoc-południe i wschód-zachód. Bo Polska to największy kraj regionu. Swoje rozważania puentuje jednak ostrożnie: Nierealne? Na dziś $z$ pewnościa. Powtórzmy jednak, że przy obecnej dynamice sytuacji międzynarodowej wszystko jest w najblizszych latach możliwe. Fortes fortuna iuvat ${ }^{57}$. Podobnie uważa Zenderowski: Polska to naturalny przywódca, zaś regionalne sojusze są koniecznością, której nie są w stanie zrozumieć elity: Mrzonką nazywają to niedoroste do tej idei politycznej elity. To w nich leży główny problem, a nie w rzekomej utopijności przedsięwzięcia ${ }^{58}$.

Odwołania do idei Międzymorza pojawiły się w kampanii wyborczej w 2015 r. - zarówno w programie Prawa i Sprawiedliwości, jak i (znacznie konkretniej i mocniej) jako jeden z głównych motywów kampanii prezydenckiej Andrzeja Dudy. Dopiero po wyborach zaczęło się doprecyzowywanie ogólnej koncepcji w program, główną rolę w wykuwaniu projektu Trójmorza odegrał prezydent Duda i minister Krzysztof Szczerski. Początkowo prezydent używał zamiennie określeń: Międzymorze i region ABC (Adriatyk, Bałtyk, Morze Czarne), jednak wkrótce przyjęto określenie Trójmorze jako bardziej neutralne, wobec niezbyt pozytywnych konotacji, jakie miało historyczne pojęcie Międzymorza dla niektórych partnerów.

Pierwsze przymiarki do organizacji nowego forum współpracy miały miejsce w Nowym Jorku, na 70. Sesji Zgromadzenia Ogólnego ONZ we wrześniu 2015 r., jednak wtedy nie przyniosły one konkretów. Oficjalna inauguracja Inicjatywy Trójmorza nastąpiła dopiero rok później podczas szczytu w Dubrowniku 25-26 sierpnia 2016 r. Inicjatorami spotkania byli prezydent Chorwacji, Kolinda Grabar-Kitarović oraz Prezydent RP, Andrzej Duda ${ }^{59}$.

${ }^{56}$ M. Kuź, Zamilknąć nie znaczy zapomnieć, http://nowakonfederacja.pl/za milknac-nie-znaczy-zapomniec/ (dostęp: 24.08.2019).

57 J. Bartosiak, Polska droga od słabości do sity, http://nowakonfederacja.pl/pol ska-droga-od-slabosci-do-sily/ (dostęp: 24.08.2019).

58 Kropla draży skatę. Z prof. Radosławem Zenderowskim rozmawia Bartłomiej Radziejewski, https://nowakonfederacja.pl/kropla-drazy-skale/ (dostęp: 24.08.2019).

59 P. Ukielski (2018): Inicjatywa Trójmorza w polskiej polityce zagranicznej, Studia Europejskie, nr 2, s. 45-46. 
W szczycie w Dubrowniku udział wzięly delegacje różnej rangi. Uczestniczyło w nim 6 głów państw: jego inicjatorzy, prezydenci Chorwacji Kolinda Grabar-Kitarović i Polski Andrzej Duda, ponadto prezydenci: Węgier János Áder, Litwy Dalia Grybauskaite, Słowenii Borut Pahor i Bułgarii Rosen Plewneliew. Udział wzięli też: wicepremier Słowacji ds. inwestycji i informatyzacji, Peter Pellegrini, minister transportu Czech, Dan Ťok, minister transportu Rumunii Petru Sorin Buşe, wiceminister spraw zagranicznych Austrii Michael Linhart, podsekretarz stanu w MSZ Estonii Väino Reinart oraz dyrektor departamentu polityki tranzytowej w ministerstwie transportu Łotwy, Andris Maldups ${ }^{60}$. Wpływ na zróżnicowany status poszczególnych delegacji miało to, że szczyt był organizowany stosunkowo pospiesznie, zaś jego cele nie zostały całkiem jasno określone. Pojawiła się też obawa, że nowa inicjatywa będzie miała charakter polityczny o ostrzu skierowanym przeciw Rosji lub przeciw Niemcom i Unii Europejskiej. Takie obawy były zresztą wprost formulowane po szczycie w Dubrowniku m.in. w mediach niemieckich ${ }^{61}$.

Szczyt w Dubrowniku wciąż nie dawał pełnej odpowiedzi co do charakteru inicjatywy, choć widać było już wówczas, że ewoluuje ona w kierunku infrastrukturalno-gospodarczym. Obiekcje Niemiec i Unii Europejskiej powodowały też spore wahania państw uczestników samej Inicjatywy, które dodatkowo nie były zainteresowane żadną nową formą Międzymorza w warstwie politycznej czy tożsamościowej. Powodowało to duże problemy polskiej dyplomacji przygotowującej kolejny szczyt Trójmorza $a^{62}$. Przełom nastąpił wraz z deklaracją udziału w szczycie ze strony Donalda Trumpa, prezydenta USA.

W drugim szczycie Inicjatywy udział wzięli prezydenci: Bułgarii Rumen Radev, Chorwacji Kolinda Grabar-Kitarović, Estonii Kersti Kaljulaid, Węgier János Áder, Litwy Dalia Grybauskaite, Łotwy Raimonds Vējonis, Rumunii Klaus Iohannis, Słowacji Andrej Kiska i Słowenii Borut Pahor, ponadto przewodniczący Izby Poselskiej Parlamentu Republiki Czeskiej Jan Hamáček oraz ambasador Republiki Austrii w RP Thomas M. Buchsbaum. Gościem specjalnym był prezydent USA, Donald Trump. Ranga delegacji znacząco wzrosła w porównaniu ze szczytem założycielskim, co bez wątpienia należy wiązać $\mathrm{z}$ wizytą prezydenta Trumpa.

W latach 2015-2017 w znacznej mierze wykrystalizowała się koncepcja Trójmorza. W tym czasie wyewoluowała w stronę mocno odpolityzowanej,

60 Ibid., s. 46.

${ }^{61}$ Deutschlandfunk: Trójmorze zamiast Unii Europejskiej?, http://www.dw.com/ pl/deutschlandfunk-tr\%C3\%B3jmorze-zamiast-unii-europejskiej/a-36008924 (dostęp: 26.08.2019).

62 P. Kowal, A. Orzelska-Stączek, op. cit., s. 43. 
infrastrukturalnej współpracy w ramach UE. Jak uznano, jedynie w ten sposób można było przełamać opory i zmniejszyć obawy, że inicjatywa ta stanowi wyraz polskich nadmiernych ambicji politycznych $\mathrm{w}$ regionie, jest skierowana przeciw Niemcom i Unii Europejskiej lub ma ostrze antyrosyjskie. Nie tylko w deklaracjach, ale również $w$ innych dokumentach wytworzonych w ramach Trójmorza, podkreślana jest jego komplementarność z UE. Na pierwszym slajdzie prezentacji katalogu potencjalnych projektów trójmorskich na szczyt w Warszawie prezentowanym przez stronę chorwacką czytamy, że główne cele Trójmorza są w pełni kompatybilne z trzema podstawowymi dokumentami UE:

- Strategia energetyczna 2030 (2030 Energy strategy),

- Jednolitym rynkiem cyfrowym (Digital single market),

- Mapa drogowa do jednolitego europejskiego obszaru transportu (Roadmap to a Single European Transport Area) ${ }^{63}$.

Analizując drogę, którą koncepcja ta przeszła w tym czasie, Paweł Kowal doszedł do następujących konkluzji: Doszło do 1) zerwania z nawiązaniami do znanych $z$ historii projektów Międzymorza i $A B C$ i do jej radykalnego odpolitycznienia; 2) oparcia inicjatywy wyłącznie o panstwa należace do UE, a więc pominięcia Ukrainy, ale też zmniejszenia potencjalnego oporu Rosji; 3) wprowadzenia do obrotu nowej nazwy Trójmorze i state zaznaczenie odrębności tej koncepcji $w$ stosunku do Międzymorza; 4) uznania, że podstawa wspótpracy będą kwestie energetyczne i infrastrukturalne, co w polskiej polityce wewnętrznej przesuwato środek ciężkości zajmowania się kwestia Międzymorza/Trójmorza z Kancelarii Prezydenta do odpowiednich ministerstw, a $w$ sensie finansowym - zatożenie wsparcia przez instytucje unijne; 5) uznania, że w kwestiach bezpieczeństwa Trójmorze opierać się będzie na wspótpracy $z$ USA ${ }^{64}$.

Takie zdefiniowanie roli, zasad funkcjonowania i celów Inicjatywy Trójmorza można uznać za realizację postulatu Michała Kuzia, żeby nie mówić za wiele o wielkich planach geopolitycznych, o ambicjach przewodzenia $\mathrm{w}$ regionie, a nawet $\mathrm{w}$ ogóle nie do końca werbalizować swoje zamiary, lecz skupić się na usypianiu czujności innych graczy ${ }^{65}$. Biorąc pod uwagę istotną zmianę nastawienia Niemiec i UE do Trójmorza, która zaszła w 2018 r., można mówić przynajmniej o częściowym powodzeniu tej taktyki przełamywania oporów i niechęci ${ }^{66}$. Podczas szczytu w Bukareszcie w $2018 \mathrm{r}$. zwrot ten w mocnych słowach zadeklarował

63 Project Catalogue. Three Seas Initiative. Cohesion, Connectivity, Competitiveness, prezentacja przygotowana przez Pricewaterhouse Coopers na szczyt w Warszawie, w zbiorach autora.

64 P. Kowal, A. Orzelska-Stączek, op. cit., s. 46-47.

${ }^{65}$ M. Kuź, Zamilknąć...

66 Zob. P. Kowal, A. Orzelska-Stączek, op. cit., s. 81-84. 
Jean-Claude Juncker: Straciliśmy okazję, by pozytywnie odpowiedzieć na zaproszenie od prezydent Chorwacji dwa lata temu i na zaproszenie od rzadu polskiego rok temu. Ale jesteśmy tu dziś, bo uważamy, że to, co robicie, czego siępodejmujecie, uzupetnia działania Unii Europejskiej, które stara się ona zrealizowa ${ }^{67}$.

Trudno jednak nie zauważyć, iż pojawiające się deklaracje, że Inicjatywa Trójmorza w żadnym stopniu nie jest geopolityczna, strategiczna czy nawet polityczna, nie mogą być uznane za całkowicie prawdziwe. Bez wątpienia nie jest ona sojuszem militarnym czy jakimś spójnym blokiem politycznym między Rosją i Niemcami, jednak takie sfery, jak infrastruktura czy (zwłaszcza) energetyka, są również dziedzinami o znaczeniu strategicznym i wpływają na bezpieczeństwo. Zaznaczał to zresztą jeden z twórców politycznej koncepcji Trójmorza minister Krzysztof Szczerski: Inicjatywa Trójmorza nie jest więc projektem ściśle geopolitycznym, choć może być postrzegana jako odpowiedź na zagrożenia geopolityczne dla Europy Środkowej $i$ Wschodniej. Im mniej jesteśmy rozwinięci gospodarczo i zintegrowani, tym łatwiej stracić nas w przestrzeń rywalizacji geopolitycznej mocarstw ${ }^{68}$.

Można zatem Inicjatywę Trójmorza uznać za zredukowaną do postaci możliwej do realizacji w obecnych warunkach wersję Międzymorza, jak to czyni Bartłomiej Radziejewski: Po latach rozbijania się naszych postulatów nowego Międzymorza i „przywództwa Polski w regionie” o désintéressement środkowoeuropejskich sojuszników, obóz PiS-u, całkiem trzeźwo, dokonat redukcji ambicji: skoro wielki projekt jest obecnie niemożliwy, bo jesteśmy na jego przeprowadzenie za słabi, zacznijmy od czegoś mniejszego, akceptowalnego tak dla zewnętrznych mocarstw, jak i regionalnych sojuszników, co zarazem przyblizy ów cel wielki i strategiczny poprzez budowę „bazy”: potaczeń infrastrukturalnych, które zintensyfikują handel i inne wspótzależności między krajami regionu. Prowadzi go to konkluzji: „Sensem (geo)politycznym Trójmorza jest więc przybliżenie Międzymorza ${ }^{69}$.

Inicjatywa Trójmorza jest najnowszym polskim projektem międzynarodowym w regionie, w ostatnim okresie budzącym najwięcej zainteresowania i zaangażowania wśród decydentów oraz najciekawsze dyskusje i polemiki w gronie ekspertów i publicystów. W ciągu trzech lat istnienia okrzepła, zbudowała swoją markę i, przynajmniej częściowo, była w stanie poprawić swój nie najlepszy (zwłaszcza na zachodzie Europy) wizerunek. Jej ewentualne dalsze realne sukcesy są uzależnione od woli politycznej, ale, co bardziej istotne, od

67 Cyt. za: ibid., s. 84.

${ }^{68}$ K. Szczerski (2017): Utopia Europejska. Kryzys integracji i polska inicjatywa naprawy, Kraków: Biały Kruk, s. 251.

69 B. Radziejewski, Granice opcji niemieckiej, https://nowakonfederacja.pl/gra nice-opcji-niemieckiej/ (dostęp: 27.08.2019). 
sukcesów infrastrukturalnych i inwestycyjnych projektów realizowanych pod jej egidą. Wymaga to cierpliwości politycznej i pracy długofalowej - większość sztandarowych projektów to wielkie i drogie inwestycje, których realizacja potrwa latami.

Można zaryzykować twierdzenie, że właśnie tego w dotychczasowej polityce Polski w regionie brakowało - ciągłości i długofalowej konsekwencji. Radykalne zmiany myślenia o sąsiadach, które zachodziły wraz z kolejnymi zmianami władzy w Polsce, nie pozwalały budować w Europie Środkowej wizerunku Polski jako partnera stabilnego i przewidywalnego, którego zainteresowanie nie podlega krótkoterminowym fluktuacjom. Co więcej, można było odnieść wrażenie, że przez wiele lat postulaty były definiowane od ściany do ściany - od wizji polskiego silnego przywództwa w regionie po całkowity brak zainteresowania państwami środkowoeuropejskimi lub założenia, że Polska nie ma wystarczającego potencjału, by budować swoją pozycję w regionie. Postawy te cechowały zresztą nie tylko decydentów, ale (być może nawet w większym stopniu) komentatorów i publicystów. Obie te skrajności łączył ważny wspólny mianownik - charakteryzowały się swego rodzaju lekceważeniem potencjalnych partnerów, czy to z pozycji: jesteście mali, powinniście się nas stuchać, czy to: jesteście mali, nic nie znaczycie, nie będziemy z wami się zadawać, bo gramy $w$ wyższej lidze. Wiąże się to z czynnikami zewnętrznymi, na które Polska nie ma wielkiego wpływu, takimi jak silni gracze zewnętrzni, którzy potrafią rozgrywać kraje regionu, ich rozbieżne interesy czy spory i konflikty między nimi ${ }^{70}$.

W efekcie Polsce udało się zbudować dobre relacje bilateralne z państwami regionu położonymi od niej na południe i rozwinąć współpracę sąsiedzką. Grupa Wyszehradzka jako forum konsultacji oraz - w niektórych przypadkach - podejmowania wspólnych działań politycznych na arenie UE funkcjonuje dobrze i stała się nieźle rozpoznawalną marką $\mathrm{w}$ stosunkach międzynarodowych, której znaczenie bywa przez partnerów zewnętrznych nawet przeszacowane. Trójmorze jest najnowszą koncepcją, czy może precyzyjniej mówiąc, najnowszą wersją koncepcji współpracy $\mathrm{w}$ regionie $\mathrm{w}$ formacie zbliżonym do Międzymorza. Czy będzie długofalowym sukcesem i wpłynie na wzmocnienie pozycji regionu w Europie, a co za tym idzie - pozycji Polski w regionie, okaże się w dłuższej perspektywie.

70 P. Ukielski (2016): Mapa Trójmorza. Przegląd punktów wspólnych i rozbieżności w polityce 12 państw regionu, Centrum Analiz Klubu Jagiellońskiego, Raport 3, s. 31-32, https://klubjagiellonski.pl/wp-content/uploads/2018/06/raport-3-2016.pdf 